\title{
The Congolese »Crab Basket «: A Matter of What Interests?
}

\section{Quentin Laurent ${ }^{*}$}

\begin{abstract}
This paper draws on the question of the actors' interests during the last phase of the Congolese transition. Theses interests should not be solely understood through the lens of the pursuit of power and control of moribund Congolese state. Instead, their diversity can be traced at all levels of the society, among all kinds of actors and also in the regional and international orders. One of the main issues of Congo's "pacification « lies in the fact that these interests have mainly been addressed with little consideration for the idea of common good. Finding a solid ground where competing interests could express themselves in a »sub-optimal« manner is the challenge Congo and its partners are now facing.
\end{abstract}

Keywords: International community, DR Congo, failed state, interests, integration

\section{Pacification from outside?}

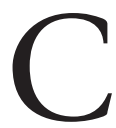

rab is not a particularly popular or common dish in Congo. With only 37 kilometers of sea coastline, the gives its fishermen the opportunity to fill their creels with many crabs. Fortunately, the brackish waters of the Congo river have endowed Congo with cossa cossa - a sort of local shrimp - which is much appreciated by Western expatriates in Kinshasa for its tasty flesh.

The existence of cossa cossa allows a French popular saying to make sense in the context of the Congo. Politics in Congo is like a »crab basket «: those inside the basket silently wolf each other down, but putting a hand in the basket will lead to a truce just long enough for the hand to be torn apart by the crabs. Like crabs, cossa cossa bite hands and feed themselves with the bodies they find in their ecosystem. On the larger scale of the Congo, it is unclear whether one should see the whole country has been thrown into a cossa cossa basket, or whether it is just a gigantic basket of cossa cossa, waiting for foolhardy hands to show up.

A great interest of the Congo lies in the interests of those competing for survival; from the relegated Kinshasa urban poor striving to gather enough food to see the light of another day, to the »big man « struggling to keep his »position of accumulation «. But why are these interests apparently so crucially rivaling? What do they boil down to, and why is the end of the Congolese transition and the election a good place to try to draw a consistent, static picture of these interests? What are the respective parts played by endogenous and exogenous interests?

Understanding what the crabs compete for requires a differentiated approach of what the idea of »interests « means. At the macro scale of international politics, »interest «is synonymous

\footnotetext{
* Quentin Laurent was a Political Advisor to Eufor RD Congo's Force Commander for the time of the operation, from July to December 2006. He had previously worked for the French Department of Defense on the African Great Lakes dossier, at the Délégation aux Affaires stratégiques (DAS). He holds a Master's Degree from Sciences Po Paris, and a Master of International Affairs from Columbia University. This article is a modified version of a paper presented at the »Congo: Pacification from Outside? « conference organized by the Institute for Peace Research and Security Policy (IFSH) and the Institute for Theology and Peace (ITHF) in Hamburg, in February 2007.

1 The country will indifferently be referred to as either DRC or Congo in this article. When the Republic of Congo is mentioned, it will be referred to as »Congo-Brazzaville $\ll$.
}

with the realist idea of national interests, grand politics, and the struggle of states for power. In an economic sense, interest is closer to the relative idea of "return « - a negotiable price one gets through an exchange or a loan. At a micro sociological scale, »interests « explain individual or group preferences, cultural features, and choices (rational or not). The Congolese electoral process was an opportunity to grasp these sets of interests which, for a short moment, became a little more still and steady than usual, after the continuous succession of crises that started in spring 1994 with the influx of Rwandan refugees into then Zaire.

One of the key features of this special moment at the end of the transition is that the stakes are extremely high for the actors. Stakes and interests are thus almost synonymous in this major political reshuffle, which combines the old interests of those involved in the Congolese crisis, and the new challenges of the (hopeful) reconstruction to come. One of the main features of this reshuffle is that it rests in an imperfect balance between internal and external processes, where inside and outside are in fact often entangled. Eufor RD Congo has been in quite a privileged position to understand them, and this allows me to draw the following few lessons.

\section{Congo in its regional environment: ending the crisis of integration?}

The statement that the Congolese war of 1998-2003 may constitute the »First African World War « is commonplace. It is, however, true in the sense that Congo's neighbors' interests, a majority of whom have intervened militarily in the country, have had a decisive influence in the rise and developments of the Congo grand crisis from 1996 to 2006.

\subsection{Regional appeasement}

The months that preceded the beginning of the electoral process saw a decrease in tension in the region, most notably with regional "godfathers « of past rebellions, namely Rwanda and Uganda. There has been a form of aggiornamento in Rwanda's policy toward Congo, which took the form of accepting Congo as indivisible. Kigali's major interests are now safe, as Kinshasa, 
with the help of the international community, seems committed to addressing the issue of the FDLR combatants, and has guaranteed that Rwanda's economic interests ${ }^{2}$ in eastern Congo will be preserved. An institutional guarantee of this last point is even provided by the Congolese constitution of December 2005, which establishes quite a decentralized governance structure for the country and its economic management.

Overall, this partial yet encouraging tacit settlement has had three main consequences for the Congo, which were observable during the very end of the transition. First, there has been a shift in the "geographical physiognomy « of the Congolese crisis, with tensions in the eastern Congo no longer capable of shaking the country to the point of collapse ${ }^{3}$. Second, the relative soothing of the Kigali-Kinshasa relations has had very differentiated consequences in terms of internal, electoral politics. Kabila's popularity was soaring in the East, as he enjoyed his reputation as a »local«, and most importantly of a »peace maker «, among the populations who suffered the worst of the war. But for the same reasons, the incumbent president invited resentment and hatred in the West and in his capital city, where he was seen as foreigner ${ }^{4}$ and a weak lackey of Rwanda. Third and consequently, this example illustrates the importance for the international community to secure "pacification from outside « at the regional level in order for an operation like Eufor RD Congo to succeed. Indeed, the European force would not have had the strength to carry out the same mandate if Eastern Congo had not had an acceptable level of peace ${ }^{5}$. Brokering a consensus with Rwanda and the other regional powers therefore was an important part of the preliminary diplomatic efforts made by the European Union to have the principle of an operation accepted ${ }^{6}$.

However, the prospect for potential destabilization from outside in Congo's regional environment is still alive, and it takes forms that have already been witnessed in the past, notably »conflict creep «. In that respect, the situations in Sudan, Chad and Central African Republic are of concern for Congo. In any case, and despite the goodwill shown by other neighbors in the resolution of the situation (e.g. Burundi, Congo-Brazzaville, Gabon), one should not forget that the »interests « Congo represents may be ones that imply survival for the

2 This also implies security considerations, such as guaranteeing a level of safety for the Congolese "Rwandan" populations in Eastern Congo, and allowing a certain level of trans-border trade and migrations between the two countries.

3 The taking of the Eastern city of Sake by Laurent Nkunda's rebels in November 2006 had virtually no consequences on the overall stability of Congo. The same cannot be said of the 2004 sack of Bukavu and of the combats around Kanyabayonga the same year. The former event notably led to a wave of popular unrest in Kinshasa that mostly took MONUC personnel as a target.

4 The mystery that persists around Kabila's youth and origins did not help him in that respect. The president was often accused of being »Rwandan Tutsi«, by his mother's blood.

5 In fact, the four Eastern provinces of Province Orientale, North Kivu, South Kivu and Maniema were not part of Eufor's area of operation. The reason for this was that the MONUC already had approximately 12,000 men deployed in this region, which was considered sufficient to secure the electoral process. Had these provinces been included in Eufor's area of operation and presented major risks of instability, it is doubtful whether the European Union would have committed itself to such an operation - or at least, it would have been a totally different operation, with extended capacities and personnel.

6 This may have already been the case in 2003, when Rwanda was initially very reluctant to a French-led European intervention in Ituri. It appeared at this occasion that Uganda's willingness to cooperate with the EU was also a way to put Rwanda in a difficult position. régime. Angola has already demonstrated in the past that it would do anything to prevent the revival of a movement such as UNITA; Uganda has interests in Ituri it cannot simply give up for the sake of keeping stability in Kampala. The coming months will also see Congo as a »re-nascent «state, having to assume certain responsibilities it had been exempt from for a long time as a »failed state «. Beyond examples taken from sheer security issues, the case of trans-border migrations to Angola has already started to create tensions with this country. Even in a peaceful environment, neighbors' interests per se may not necessarily be played down.

Finally, one should not forget that the crab basket situation of Congo is also illustrated by the persistent instability and violence in the Eastern part of the country. Disarming campaigns have had mixed results in Ituri, numerous rebel groups are still active in the Kivus, and Laurent Nkunda's forces still constitute a reserve available for a destabilization campaign in case of a reversal of alliances and agreements that were reached at the national level.

\subsection{Strategic rivalries and economic competition}

At a much lower scale of intensity, the »Congolese « stake is still a field for the expression of competing regional interests. Specifically, the game of positioning strategic and economic interests can very much be played at the sub-regional level. It should be noted here that the Congo is a member of two rival organizations, $\mathrm{CEEAC}^{7}$ and $\mathrm{SADC}^{8}$, which are as much sub-regional organizations as leverages and entry points for the respective interests of the two local hegemons - Angola and South Africa. Naturally these two actors' interests are not necessarily opposite, and Congo knows very well how to make a clever use of its powerful neighbors' rivalry ${ }^{9}$.

In fact, it could be argued that part of the Congo's problem stems from the numerous and cumbersome »friends « for whom the Congo has become a »political market « where they exert their respective strategies of influence, even for the sake of peace and stability. The example of Security Sector Reform ${ }^{10}$ (SSR) illustrates how Congo is at the same time a stake for external powers, and makes use of the political space thus created to gain independence and remuneration. In this game, sub-regional organizations themselves are not the clumsiest actors: during the electoral process, the SADC and the CEEAC respectively attempted to launch military operations similar to Eufor, in order to succeed or complement it. The lack of means and time, as well as rivalries between states defeated

\footnotetext{
7 Communauté Economique des Etats de l'Afrique Centrale. 8 Southern African Development Community.

9 Economic interests appear to be dominant in the case of South Africa (size of the Congolese market and mining potential), while Angolan concerns are more focused on security issues (securing access to the Cabinda enclave, controlling the influx of Congolese emigrants and making sure UNITA is dead for good). For a detailed analysis, see T. Turner, "Angola's Role in the Congo War « in J. F. Clark (ed.), The African Stakes of the Congo War. 2002, New York, Palgrave MacMillan, pp. 75-92 and M. Nest, F. Grignon and E. F. Kisangani, The Democratic Republic of Congo. Economic Dimensions of War and Peace. 2006, Boulder, International Peace Academy, pp. 91-92, 134.

10 South Africa and Angola are significantly involved in this multi-faceted process of SSR. For a detailed analysis, see International Crisis Group, Security Sector Reform in the Congo. Africa Report n¹04, 13 February 2006.
} 
these initiatives, which were mostly ways to assert the respective roles of the South African and Angolan hegemons in Congo, while taking advantage of a hypothetical European funding contribution.

\section{Settling an internal power and governing the Congo}

In the multi-layered disorder of Congo, the issue of pacification is one that borrows both from the inside and the outside, and largely stems from what has become a cliché to call the »failed « nature of the Congolese state. The situation is in fact very close to the one described by Kisangani ${ }^{11}$, where in Congo's history, each new attempted institutional setting is "polluted « by unsolved issues from previous attempts, and may greatly impact the relations of Congo with its neighbors ${ }^{12}$, not even to mention its internal stability. Thus, pacifying the Congo probably requires, above all, ruling the country. At long last.

\subsection{Ending war, beginning democracy}

One of the most original aspects of the difficult process of bringing Congo to peace and democracy lies in what has been described as »winner takes all $«$ politics ${ }^{13}$. This concept partly echoes with the history of Congo, and the idea of domination by a deceptive and kleptocratic ${ }^{14}$ state under Mobutu, which seriously hampers the building of a representative, impartial state apparatus, let alone an efficient one. The »winner takes all« culture found a sad illustration in its collision with the international community's plans in the heart of Kinshasa on August $20^{\text {th }}-22^{\text {nd }} 2006$.

While the final results of the first round of the presidential election were being announced, violent confrontations (involving heavy weapons and tanks) took place between the president's Republican Guard and vice-president Bemba's forces. For three days, the security situation remained very volatile and the combat claimed dozens of lives. On this occasion, Eufor successfully intervened at the request and with the cooperation of the MONUC, and interposed itself between the two parties.

This development brought the transition to the edge of collapse, and it illustrates two important points about the incumbent president. First, an electoral defeat was inconceivable in his eyes ${ }^{15}$; second he needed to appear as a strong man in the

11 M. Nest, F. Grignon and E. F. Kisangani, op. cit.

12 The issue of nationality being an obvious example of this process. For a complete analysis, see J.-C. Willame, Banyarwanda et Banyamulenge. Violences ethniques et gestion de l'identitaire au Kivu. 1997, Brussels, Paris, Institut Africain-CEDAF, L'Harmattan.

13 This idea belongs to P.-A. Braud, who expressed it on the occasion of several presentations during conferences.

14 J.-F. Bayart, S. Ellis and B. Hibou, La criminalisation de l'Etat en Afrique. 1997, Brussels, Complexe.

15 Joseph Kabila remains a mysterious character. Beyond the question of his origins, his genuine importance in the functioning of the Congolese executive is often questioned. According to many sources, Kabila is in great part the instrument of what is often described as a Katanga »clan « of individuals who rule Congo. Moreover, the allegiance of many of the Congolese forces in Kinshasa has always been seen as dubious, while the true intentions of Kabila's "godfather « and last resort protector, Angola, were sometimes difficult to decrypt. eyes of a public opinion who had ambivalent feelings with regard to $»$ weak rule ${ }^{16}$.

Another form of political »holism « that compromised the stability of the Congolese transition was reawakened during the electoral process and campaign: ethnic dynamics. As such, ethnicity can be used in a partly stabilizing manner, as Mobutu used it to allow a »rotatory cooptation « of the elites, but also as a ferment of dissension - which Mobutu also did, notably by exploiting the »anti-Rwandan « and »anti-Tutsi « feelings in early 1990s Eastern Zaire ${ }^{17}$.

However, the 2006 electoral campaign at the national level showed that the local actors' interests were heading to a renewed language of essentialism and identity narratives focused on the origins of the candidates, instead of pure ethnicism. This "autochthonist « platform, which Jean-Pierre Bemba's supporters' made inordinate use of, is grounded in the idea that different cultural behaviors among some Congolese groups testify to their foreign origins (not consistent with the idea of »congolité«) and their dubious allegiance to the Congo - which therefore justifies their discrimination.

Such a body of ideas is not a novelty, and has even been successful in Eastern Congo for many years, where it has become a structuring phenomenon of political identities, to varying degrees ${ }^{18}$, essentially against groups perceived as »Rwandan $«$. But the real novelty lies in the proclivity of these themes to mobilize Congolese constituency and polarize it along a linguistic line. In the West, where Lingala is spoken as a lingua franca, and where Swahili speakers are regarded distrustfully, the majority voted for Bemba (approximately 70\% of the votes). This is opposed to the East, where Swahili is the lingua franca, and where Kabila's popularity is overwhelming (approximately $90 \%$ of the votes).

Without going into the sociological details underlying such a divide, it should be noted that it poses a major challenge to the new government in terms of its ability to govern the country, which will lack the legitimacy to rule a country so profoundly divided into two blocks ${ }^{19}$. In that respect, the Congolese crabs in the basket have (once again) favored the safeguarding of their ethnic and personal interests ${ }^{20}$ in order to secure themselves a capacity of mobilization, and have abandoned the idea of acting in favor of the public good.

16 As a mirror to Kabila's reaction, a lot could be said about Bemba's "stagecraft « production of violence as a mean to catalyze popular support in Kinshasa during the electoral process. The best example of which was the incredibly brutal political rally Bemba led in Kinshasa on July 27th 2006, just three days before the first round of the presidential elections. During the massive procession, several institutions associated with Kabila's power were sacked and burnt, several policemen were brutally murdered and literally dismembered, and their limbs were exhibited by the demonstrators as trophies. Beyond an act of protest, this was also a very powerful provocation and humiliation of Kabila, who scored a weak 14\% in Kinshasa three days later, while Bemba scored close to $50 \%$ in the capital.

17 See J.-C. Willame, op. cit.

18 S. Jackson, "Sons of Which Soil? The Language and Politics of Autochthony in Eastern D.R. Congo«, African Studies Review, 49, 3, December 2006, pp. 95-123.

19 The fact that there are only two blocks involved is potentially very problematic, as the centrifugal political process is not only grounded in a multiplicity of local allegiances, but also in a strongly dual pattern.

20 The ethnic dimension is still very vivid in Congolese national politics. To many observers, Kabila's new mandate was the best way to ensure that Katangans would keep the upper hand on the country and prevent Katanga's secession. In that province, ethno-nationalist feelings were ready to be exploited by local actors in case Kabila failed to succeed in the presidential bid. 
It remains all the more true that an uncertainty prevails in terms of a potential new »cycle« of internal instability. As mentioned, the results of the institutional reform that should lead Congo on the path of formal decentralization are still unclear $^{21}$. And the temptation for the government to act in a much more centralized manner than originally expected may be as strong as that of local grievances to express themselves in a disturbing fashion, such as Bundu Dia Kongo in the Bas-Congo province ${ }^{22}$. Again, the instability and violence that still prevail in Eastern Congo cannot only be addressed by brutal repression. For this long-lasting violence has yielded a new sociological functioning that cannot be reverted in little time and with little means. The interests of local actors and militiamen in these regions are the mere translation at the level of the group and the individual of Congo's deep crisis of state and democracy integration - the elusive quest for the common good.

\subsection{Survival}

Nonetheless and unfortunately, a sociological definition of what common interest is in Congo may not be that difficult to find in the ethos of »survival «, which encompasses virtually all political behaviors and strategies, from the top to the bottom of the Congolese society. At the top, the topos of survival is somehow close to the idea of "politics of the belly ${ }^{23}$ «. This found a quasi-paroxysmic illustration during the Congolese transition, when the economic structure of the Congolese state modeled itself on the so peculiar and inefficient political structure of the time ${ }^{24}$. Thus, the economy found itself totally subordinate to politics without any consideration for the common good on the part of the actors' interests. They simply shared the "flagships « of the national economy and lucrative appointments in a way that evoked the purest patrimonialist conception of politics and a »rent economy« - where the position provided to a group of actors matters more than actual production of wealth.

But the actors of the international community have the ability to antagonize this endless quest of what the people of Kinshasa calls »bouffer« (»gobble up«) ${ }^{25}$. Opening the taps of gains such as those from international aid and cooperation, could well take less indulgence from the part of donors. At least under the condition that they fine-tune their interests

21 See S. L. Marysse, »Decentralization Issues in Post-Conflict Democratic Republic of the Congo (DRC) in F. Reyntjens and S. L. Marysse (eds.), L'Afrique des Grands Lacs. Annuaire 2004-2005. 2005, Paris, Brussels, L'Harmattan, Centre d'étude de la région des Grands Lacs d'Afrique, pp. 187-208.

22 Bundu Dia Kongo is a seemingly mystic and millenarian movement with unclear pan-Kongo ethnic group irredentist drives, who was responsible for violent actions and protest before and after the electoral process.

23 J.-F. Bayart, State in Africa: The Politics of the Belly. 1993, New York, Longman.

24 By the same token, one can make the case that the transitional model in Congo, as it was very distributive to the insiders, provided a strong incentive to enter the transition process or renegotiate one's position within the process... even by the means of violence. On this issue, see D. M. Tull and M. Mehler, »The Hidden Costs of Power Sharing: Reproducing Insurgent Violence in Africa«, African Affairs, 104, 416, 2005, pp. 375-398, and R. Lemarchand, »Consociationalism and Power Sharing in Africa : Rwanda, Burundi, and the Democratic Republic of the Congo«, African Affairs, 106, 422, 2006, pp. 1-20

25 As a matter of fact, the IMF suspended its assistance program to Congo in March 2006, in protest against the Congolese economic mismanagement. and offer a close front to the leaders of »new Congo «, who are dreaming of an even more exclusive sharing of the »national cake« (as the Nigerian saying goes).

Unfortunately, the democratic demands are also often sacrificed to the benefit of this survival logic - sometimes under the very name of democracy: the alliance brokered before the second round of the presidential election between Antoine Gizenga's PALU and Joseph Kabila's AMP is less suggestive of genuine coalition, than of a process of capturing unanimity and dismantling the few democratic advances of the end of the transition.

But the topos of survival is not only a matter of the »top «. The harshness of life in Kinshasa has turned »débrouille« (»resourcefulness «) into a foundation of social life and behavior ${ }^{26}$. For the actors of the »bottom «, survival means to demonstrate by any means one's existence. There lies the interest of the survival ethos: securing an existence position in the future political setting of Congo. Three kinds of actors deserve here a closer look: the street, moral entrepreneurs, and the figure of the »spoiler $«$.

Indeed, the »street «per se has no »interests«. But it is in the streets that one may find a great deal of political expression and mobilization. This proved particularly true in the past 15 years, through a succession of riots in Kinshasa ${ }^{27}$ and other cities, which has given a considerable power to those who know how to control and manipulate discontent from a population who is swift to rise up. The political »death « of Etienne Tshisekedi's party UDPS ${ }^{28}$, that occurred during the electoral process in which Mobutu's historic opponent refused to take part, may well be a mere episode of no consequence in terms of potential for unrest from the part of the relegated population - the security issue in Kinshasa remains as burning as it was, mutatis mutandis in $19^{\text {th }}$ century Paris. Also, popular discontent is all the more useful that peacekeepers and international interveners are utterly destitute to face it and to react against $\mathrm{it}^{29}$.

Concerning the case of moral entrepreneurs such as churches, the struggle for survival boils down to an intense competition. There exists a temptation of radicalization and even individual conflicts within these institutions - in order to remain at the center of moral and identity strategies of the Congolese ${ }^{30}$. A similar point could be made about the Congolese press, and the way it found itself trapped between the authoritarian

26 G. De Villers, J. Omasombo Tshonda, »Quand le peuple kinois envahit les rues... «, in T. Trefon (ed.) Ordre et Désordre à Kinshasa. Réponses populaires à la faillite de l'Etat. Cahiers Africains, 61-62, 2004, pp. 213-234.

27 In 1991, 1993, then in 2004, Kinshasa was shaken by popular riots, for which hunger and political discontent was the main motivation.

28 Union pour la Démocratie et le Progrès Social, party of the opposition against Mobutu under the »transition « of the early 1990s.

29 For instance, Eufor had no provision in its mandate to undertake any task of crowd control beyond cases involving self-defense.

30 The high level of politization of Congolese churches is noteworthy. Not only are they undermined by influence quarrels (such as the one that opposed cardinal Etsou and Kinshasa's archbishop Monsengwo in the Catholic church), but they also occasionally serve the interests of political actors. For instance, the hype about Kabila's allegedly foreign origins was partly calmed down by the president's religious wedding, that was carried out by cardinal Etsou in June 2006. This implies that both Kabila's parents were listed on the parish records of the Catholic church, which in turn implies that they were both Congolese nationals. On his part, Bemba extensively resorted to the sermons of popular evangelists in Kinshasa to spread his political message. 
temptations of the power in place, and its own temptation to become an ignoble outlet of hatred during the electoral process.

Finally, the figure of the »spoiler « is a fascinating one and would deserve a longer analysis. In the transitional Congo major political reshuffle, potential spoilers pose great challenges to the future stability of the country - they were even the main justification for the European intervention in the form of Eufor. But a durable solution to this problem lies in survival guarantees the losers of the electoral process should be granted with. This must be done at the price of very »political« compromises, but also by simply letting an opposition exist. To promote such interests, the pressure and the expertise of the international community may be of help to a certain degree.

\section{Conclusion: the international community, the God Janus of the Congo}

As a conclusion, the picture of the international community's interventionist interests in Congo ${ }^{31}$ deserves a closer look. Such an interventionism is indeed capable of changing the future of the country, for the better or the worse. Thus, the face of the international community's interests resembles the god Janus - god of crossroads, of wars starting and ending; a double-faced god looking at the same time at Congo's specific needs and stakes, and at abstract and general issues shared by the rest of the world.

How to define, then, the relationship between the very vernacular process of reshuffle that is still taking place in the Congolese »crab basket «, and the »international interests « in their vast diversity? What are the key points of tension that provide a perspective on how these different sets of interests are articulated? There are three major fields in which they interact, namely legitimacy, cooperation and imputation.

Legitimacy is indeed something that the Congolese actors and the »international community « are striving for at the same time, but not necessarily in the same direction. The quest for legitimacy typifies the hesitations of the international community. On the one hand, there is a temptation for a dangerous disengagement, now that the situation is seemingly stable in Congo. The debates concerning the future of the MONUC or of a body such as ICST ${ }^{32}$, who could well be both shorter-lived than expected, illustrate this point. But on the other hand, there is also a temptation for a staunch revival of influence and national interests policies toward Congo. Indeed, these must be accepted to some extent. The United States' security concerns over the control on Congo's uranium is understandable. France's drive to defend the largest French

31 Some even call Congo an »internationalized « state. See notably T. Vircoulon, "L'Etat internationalisé, nouvelle figure de la mondialisation en Afrique«, Etudes n4061, January 2007, pp. 9-20.

32 International Committee for the Support of the Transition. Unsurprisingly, the newly elected Congolese government is very much more prone to treat on a bilateral basis with his international partners than in a multilateral body such ICST (established under a chapter VII UN resolution), which is generally more demanding in terms of governance and democratic standards. speaking country on earth is also logical. So is Germany's interest in taking the lead of Eufor, in order to consolidate its nascent status of world political power. But such drives remain legitimate in the eyes of the Congolese (and in the eyes of the home countries' public opinions) and potentially beneficial to Congo only as long as they demonstrate a minimal level of coordination and fairness.

Cooperation is a correlate of legitimacy. Eufor's success (that followed the success of operation Artemis in 2003) shows that initiatives that are implemented by actors who are gathered in a common binding mechanism can yield positive results. Indeed, the EU has adopted this tactics in Congo through the multiplication of missions ${ }^{33}$ that address different kinds of actors and issues in a customized and reactive fashion - and thus create positive interactions with other international bodies (MONUC, regional organizations, neighboring countries, etc.). Cooperation thus implies a Hobbesian process that creates obligations between actors who renounce their most brutal ways of promoting their interests. It should be pursued further with regional actors who partly have the key to Congo's stability: Angola, Rwanda and Uganda.

But at the same time, cooperation should be kept away from the inherent risk of compromising with what is not acceptable. For instance, beyond competing interests, international actors should keep alive the UN panel mechanism monitoring arms trafficking. Congo should also be kept under pressure as regards to the economic assistance it will enjoy, and receive adequate support if it deserves so $^{34}$.

Finally, imputation hazard is usually at the same time the price of success and a multiplier of failures. It requires that involvement on the one hand (in order to overcome the idea that international community's interventionism is only »interstitial $^{35}$ « and does not »care« about Congo's misfortunes), and distance on the other hand (in order to prevent the development of a »moral hazard « effect among other local or international actors ${ }^{36}$ ) be well balanced.

»Going too far « in terms of international involvement also bears the risk of exacerbating xenophobic and nationalistic feelings in the population, who is just starting to recover from years of suffering and humiliation. Conversely, not everything (especially not the drive to conduct »just « policies) should be sacrificed on the altar of »stability«. An operation like Eufor may have been a success, it still means very little if it is not followed by consistent and ambitious policies, together with

33 Most notably Eusec (mission in support of the restructuring of the Congolese army) and Eupol (mission in support of the Congolese police), but also the European Electoral Observers mission.

34 The international community of donors has often privileged assistance to certain other countries. Congo has often been the "poor parent « of this practice, as shown by S. Marysse, A. Ansoms and D. Cassimon, »Les >chouchous< et les >orphelins` de l'aide dans la région des Grands Lacs: la géopolitique des flux financiers« in L'Afrique des Grands Lacs. Annuaire 2005-2006. 2006, Paris, Brussels, L'Harmattan, Centre d'étude de la région des Grands Lacs d'Afrique, pp. 119-147.

35 This idea is borrowed from Ghassan Salamé, as cited by R. Marchal and R. Banégas, »Interventions et interventionnisme en Afrique«, Politique Africaine $\mathrm{n}^{\circ} 98$, June 2005 , pp. 5-19.

36 This idea of "moral hazard « (taking away the sense of responsibilities of local actors) was very vivid during the Congolese transition, as international missions such as Eufor would soon be considered by Congolese leaders as in charge of every aspects of the local security. The alleged "passivity« of the MONUC also ensues from this idea. 
advocacy for a real change in the way local and regional actors craft and defend their »Congo interests«.

So, interventionism is like »interest «, a sensitive and paradoxical topic. A little bit like the food in a hotel in the Woody Allen's movie »Manhattan«: it is at the same horrible and there is not enough of it either.

The aim of this paper was to show that the variety and the conflicting nature of interests in Congo accounts a lot for this country being what many see as a »crab basket «. That is, a construction in which the satisfaction of interests will either never be grounded on compromise, or will entail such a dramatically sub-optimal level of compromise, that it will not even be desirable. At the same time and paradoxically, Congo has also long suffered from a crucial lack of interest from the part of the international community, that partly left it slipping on the slope of tragedy and collapse, in a war that lasted seven years.

Thus, the new exciting challenge Congo is now facing is not really to bridge a gap between various rival interests competing at various levels. It is rather to find an acceptable manner of having these interests competing, on a ground that is not necessarily detrimental to the common Congolese good, and to the building of an acceptably democratic and accountable state. In short, a way to put the crabs out the basket.

\title{
Ethical Reflections on the Intervention of the UN and EUFOR in the D.R.Congo
}

\section{Paulin Manwelo*}

\begin{abstract}
This article outlines the necessity to go beyond a one dimensional approach in dealing with the major crises of our time. The author advocates a »holistic « approach or what he calls the Good Samaritan Model, as an ethical response to protracted conflicts in today's world. The relative successful story of the intervention of the UN and Eufor in the crisis in the Democratic Republic of Congo is used as an illustration to support the ethics of pacification from outside based on the Good Samaritan Model.
\end{abstract}

Keywords: RD Congo, ethics, theory, intervention, conflict

\section{Introduction}

$\mathrm{I}$ intend to address four main issues in this article. First, I would like to briefly outline the problems at stake in the Congo's crisis. Second, I will critically examine the main ethical theories with regard to a foreign intervention in a country faced with protracted conflict and war. Third, in the light of this second part, I will ethically assess the intervention and the role of the UN and Eufor in the D.R.Congo. Fourth, by way of conclusion, I will highlight some pending challenges in respect to the future of the Congo and thereby some ethical principles that may constitute a solid basis for an ethics of peacebuilding based on "pacification from outside $\ll$.

\footnotetext{
* Paulin Manwelo, S.J., is a Jesuit Priest from the Democratic Republic of Congo. He received his Doctorate in Political Philosophy at Boston College, Massachusetts, U.S.A. He is currently the Director of the Institute of Peace Studies and International Relations at Hekima College, Nairobi, Kenya.
}

\section{A Brief Analysis of Congo's crisis}

There are numerous, and at times, contradictory analyses about the crisis of Congo. However, one can point out five main dimensions of the crisis affecting Congo, from independence to the present time. These five dimensions are as follows: colonialism, geostrategic equation power, political power, economic factor, and cultural pluralism.

The fact of colonialism can hardly be considered as a happy event, at least for the colonized people. Such is the case with the Congo, which was the Belgian colony Congo under King Leopold II. Historians are keen to point out that the colonization of Congo by Belgium represents the worst case among other colonies in Africa ${ }^{1}$. Unlike in other African countries colonized by the British whose approach was more pragmatic,

\footnotetext{
1 Cf. Adam Hochschild, King Leopold's Ghost. A Story of Greed, Terror, and Heroism in Colonial Africa, London: Houghton Mifflin Company, 1998.
} 